\title{
Primary Amenorrhea due to Empty Sella: An Underestimated Entity
}

\author{
Boş Sella Nedeniyle Primer Amenore: Gereğinden Az Düşünülen \\ Bir Durum
}

\author{
Nitin DANGE ${ }^{1}$, Rakesh REDHU ${ }^{1}$, Juhi KAWALE ${ }^{2}$, Amit MAHORE ${ }^{1}$ \\ ${ }^{1}$ Kem Hospital, Department of Neurosurgery, Mumbai, India \\ ${ }^{2}$ Kem Hospital, Medicine, Mumbai, India
}

Correspondence address: Amit MAHORE / E-mail: amit2mahore@yahoo.co.in

\begin{abstract}
We report a 16-year-old girl who had stunted growth and primary amenorrhea presenting with headache and vomiting. MRI of brain showed posterior fossa dermoid cyst with hydrocephalus and empty sella. Growth hormone (GH), Leutinizing hormone (LH) and Follicular stimulating hormone (FSH) were grossly reduced on endocrinological work-up. She underwent suboccipital midline craniectomy and complete excision of dermoid cyst . She had no additional deficit after the surgery. She had menarche six months after the surgery and developed adequate secondary sexual characters, however her height remains subnormal at follow-up after 2 years as compared to age matched controls. We briefly review the radiological features, pathogenesis and outcome of this underestimated entity.
\end{abstract}

KEYWORDS: Hydrocephalus, Empty sella, Amenorrhea, Dermoid cyst, Brain tumors

Öz

Başağrısı ve kusmayla gelen ve büyüme geriliği ve primer amenore gösteren 16 yaşında bir kız hastayı bildiriyoruz. Beyin MRG hidrosefali ve boş sella ile birlikte bir posterior fossa dermoid kisti gösterdi. Endokrin incelemede büyüme hormonu (GH), luteinizan hormon (LH) ve foliküler stimüle edici hormon (FSH) önemli ölçüde azalmıştı. Suboksipital orta hat kraniyektomi ve dermoid kistin tam eksizyonu yapıldı. Cerrahiden sonra herhangi bir defisit saptanmadı. Cerrahiden altı ay sonra menarş gelişti ve yeterli sekonder cinsel özellikler ortaya çıktı. Ancak hastanın boyu 2 yıllık takipten sonra yaş açısından eşleşmiş kontrollere göre halen normalin altında kaldı. Bu gereğinden az düşünülen durumun radyolojik özellikleri, patogenezi ve sonucunu kısaca gözden geçiriyoruz.

ANAHTAR SÖZCÜKLER: Hidrosefali, Boş sella, Amenore, Dermoid kist, Beyin tümörleri

\section{INTRODUCTION}

Empty sella is caused by herniation of supra-sellar cistern into pituitary fossa causing non-visualization of pituitary gland on radiological imaging. It is reported in $6-20 \%$ of autopsy specimen (1). Few case reports of intracranial tumors other than sellar-suprasellar lesions causing empty sella have been described in the literature $(8,11)$, however, its association with posterior fossa dermoid cyst has never been described in the literature.

\section{CASE REPORT}

A Sixteen years old female who had primary amenorrhea and lack of secondary sex characters developed headache and vomiting for two weeks prior to presentation to our services. On examination she had short stature with lack of secondary sexual characters. Fundoscopy showed bilateral papilloedema, rest of neurological examination was normal. Her MRI brain revealed a $4^{\text {th }}$ ventricular dermoid cyst with hydrocephalus and supra-sellar cistern herniating into pituitary fossa causing empty sella (Figures 1, 2A-B ).There was a tract extending from the dermoid cyst to subcutaneous tissue. There was no evidence of any communication with skin. Growth hormone (GH), Leutinizing hormone (LH) and Follicular stimulating hormone (FSH) were grossly reduced on endocrinological work-up. She underwent sub occipital craniectomy and complete excision of dermoid cyst with tract. Histopathology was consistent with dermoid cyst (Figure 3A). She started having menses six months after surgery. MRI of brain at follow-up showed reduction in pressure changes on pituitary gland with recovery of size, however dimensions of sella remain the same (Figure $3 \mathrm{~B}$ ). At 2 years of follow-up she has no deficit, but she has not attained adequate height as compared to her age matched controls, though her hormonal profile has become normal.

\section{DISCUSSION}

Empty sella syndrome is a radiological and anatomical diagnosis characterized by herniation of supra-sellar subarachnoid space into the pituitary fossa compressing the pituitary gland along the wall of the sella. Classically it has been described in middle aged, obese hypertensive females 


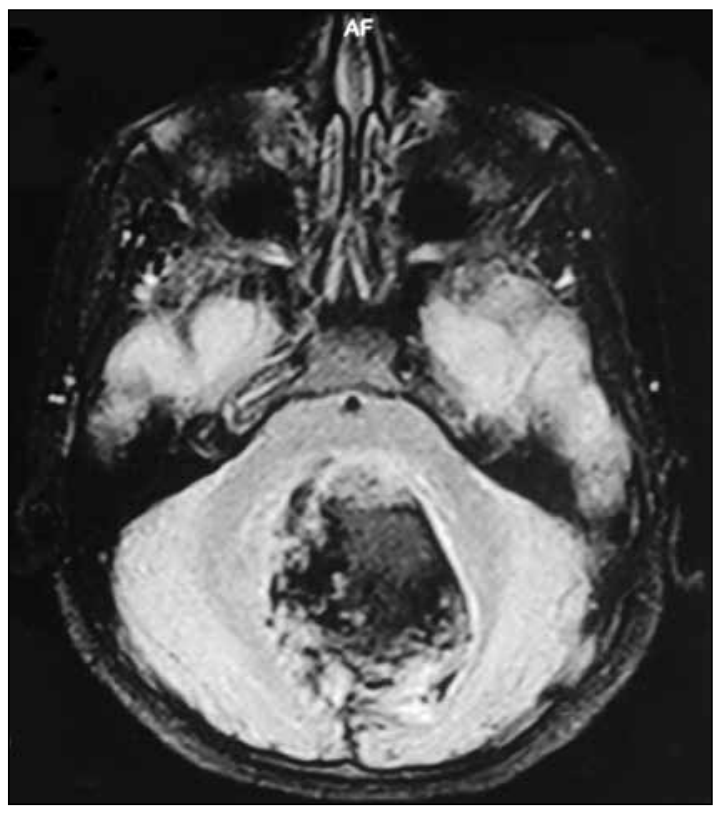

Figure 1: T1-weighted-axial image of MRI of brain showing heterogeneous space occupying lesion in the $4^{\text {th }}$ ventricle.
$(7,8)$. It may be primary empty sella where it is not associated with previous surgical intervention or radiation treatment. Secondary empty sella is the consequence of previous surgery, pharmacological or radiation treatment (9). The causes for primary empty sella are benign intracranial hypertension, hydrocephalus causing dilated third ventricle, multiple pregnancies with repeated necrosis/atrophy of gland, hemorrhage/necrosis into pituitary adenoma, post-partum pituitary necrosis (Sheehan's syndrome), cystic pituitary tumor and deficient diaphragma sella .Besides these, intracranial tumors excluding pituitary and parasellar tumors invading the sella causing raised intracranial pressure can lead to empty sella $(8,9,11)$. Recently Kim et al (8) in their description of various brain tumors for their association with empty sella have discussed the pathogenesis of this condition and possible indications for surgical intervention. They also emphasized lack of description of this entity in the literature. Diagnosis of empty sella is suggested by enlarged sella (symmetric ballooning with depressed floor) on plain lateral skull radiograph. CT will show the evidence of erosion of posterior clinoid and dorsum sella along with widening and depression of floor $(1,7,8,9)$.

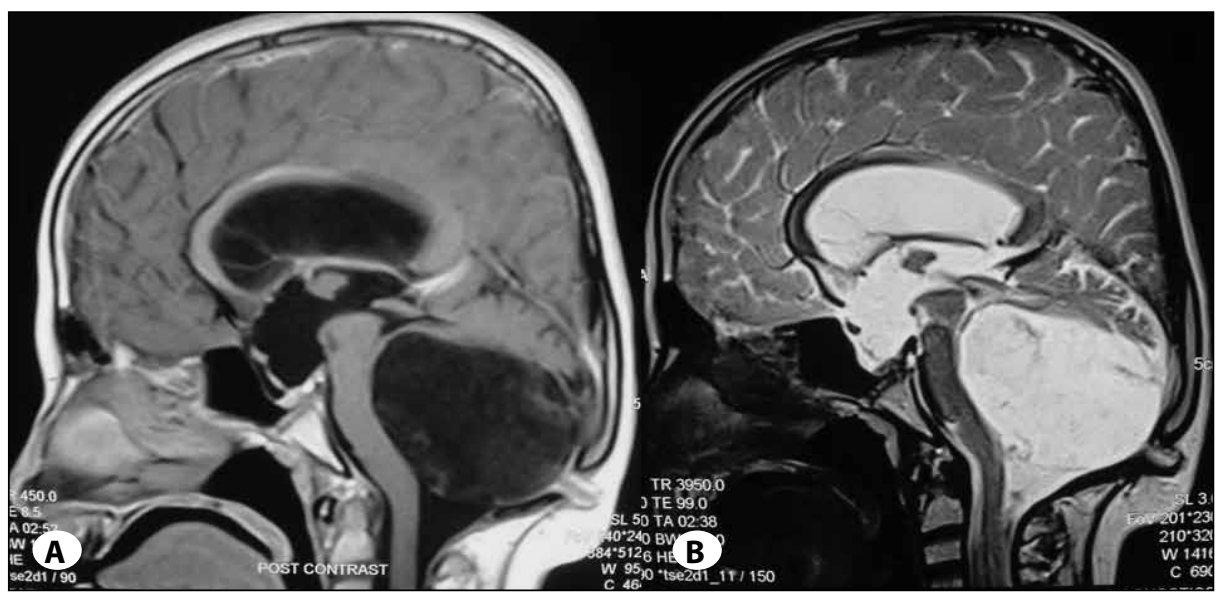

Figure 2A,B: Post contrast T1- \& T2 weighted sagittal images of MRI of brain showing heterogeneous space occupying lesion in the $4^{\text {th }}$ ventricle with empty sella and tract extending from the lesion to subcutaneous tissue.
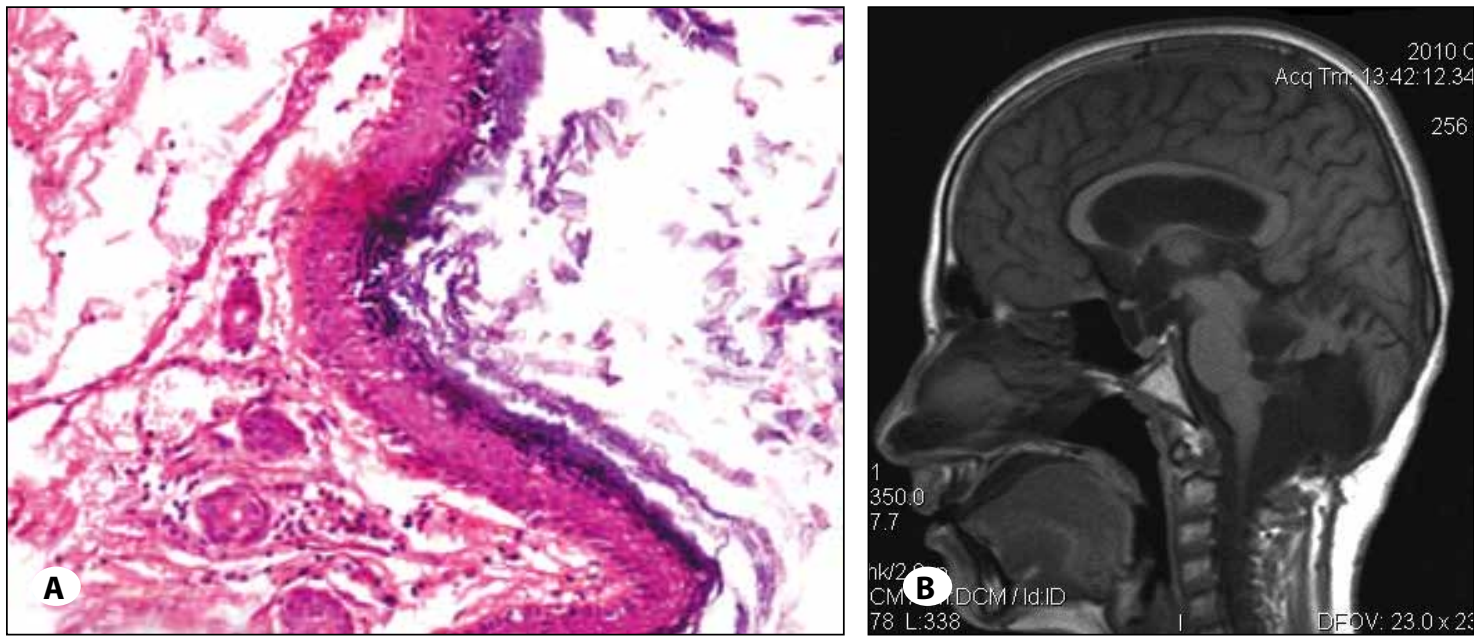

Figure 3: A) Microphotograph of histopathology showing dermoid cyst lined by squamous epithelium with underlying lamellated keratin, adnexal structuctures and hair follicles. B) Post contrast T1-weighted sagittal image of MRI of brain showing complete excision of cyst with recovery in size of pituitary gland; however dimensions of sella remain the same. 
Chronically raised pressure and dilatation of the third ventricle lead to alteration in CSF dynamics at supra-sellar cistern and its herniation into the sella turcica $(1,2,8,9)$. Chronic pressure over the pituitary gland may lead to functional alterations, most common of which is deficiency of growth hormone $(3,5$, 10) Empty sella and primary amenorrhea due to aqueductal stenosis with hydrocephalus and resumption of menses after shunt surgery have been described (2) but never in association with a dermoid cyst.

Dermoid tumors comprise $0.1-0.7 \%$ of all intracranial tumors and are mostly found in the midline. They may be extradural, vermian, or intraventricular. A dermal sinus may or may not be connected to the mass. These grow slowly over the period and manifest during adolescence $(3,4,6,10)$. Dermoid tumors arise from incomplete separation of epithelial ectoderm from neuroectoderm at around fourth week of gestation. The cyst wall often includes hair follicles, sweat glands, and sebaceous glands which secrete desquamated epithelium, sweat, and sebaceous materials causing gradual expansion of the tumor $(4,6)$. Absence of dermal communication and other features like recurrent meningitis led to late diagnosis in our patient. Fundoscopy in patients of primary amenorrhea may clinch the diagnosis of neurosurgically treatable lesions in early stage by detecting papilloedema when the other features of raised intracranial pressure might be absent. We also believe that our patient did not achieve the normal height due to late diagnosis $(3,10)$.

\section{CONCLUSION}

Primary amenorrhea may be caused by any intracranial tumor causing chronic hydrocephalus. The prognosis with benign space occupying lesions is relatively better. High index of suspicion and early diagnosis may help the patients to attain normal growth and hormonal parameters.

\section{ACKNOWLEDGEMENTS}

The authors acknowledge with gratitude the encouragement and support of Prof .Atul Goel, Head of the Department of Neurosurgery, KEM Hospital, Mumbai, India.

\section{REFERENCES}

1. Bjerre P: The empty sella. A reappraisal of etiology and pathogenesis. Acta Neurol Scand Suppl 130:1-25, 1990

2. Bousigue JY, Caron P, Adam P:Tremoulet M: Association d'une stenose de l'aquedue de slyvius d'une sella turcique vide et d'une amenorrhea primarie. Rev d'Oto-neuro-ophtalmol 56: 31-34, 1984

3. Cacciari E, Zucchini S, Ambrosetto P, Tani G, Carla G, Cicognani A, Pirazzoli P, Sganga T, Balsamo A, Cassio A, et al: Empty sella in children and adolescents with possible hypothalamicpituitary disorders. J Clin Endocrinol Metab 84:1277-1282, 1994

4. Chandra PS, Gupta A, Mishra NK, Mehta VS: Association of craniovertebral and upper cervical anomalies with dermoid and epidermoid cysts: Report of four cases. Neurosurgery 56 : E1155, 2005

5. Faglia G, Ambrosi B, Beck-Peccoz P, Giovannelli M: Disorders of growth hormone and corticotrophin regulation in patients with empty sella. J Neurosurg 38:59-64, 1973

6. Hinojosa M, Tatagiba M, Harada K, Samii M: Dermoid cyst in the posterior fossa accompanied by Klippel-Feil Syndrome. Childs Nerv Syst 17:97-100, 2001

7. Jordan R M, Kendall J W, Kerber C W: The primary empty sella syndrome. Am J Med 62:569-580, 1977

8. Kim JH, Ko JH, Kim HW, Ha HG, Jung CK: Analysis of empty sella secondary to the brain tumors. J Korean Neurosurg Soc 46(4):355-359, 2009

9. Maira G, Anile C, Mangiola A: Primary empty sella syndrome in a series of 142 patients. J Neurosurg 103:831-836, 2005

10. Pocecco M, De Campo C, Marinoni S, Tommasini G, Basso T, Muzzolini C, Sacher B: High frequency of empty sella syndrome in children with growth hormone deficiency. Helv Pediatr Acta 43: 295-301, 1989

11. von Wild K, Hobik HP, Kulali A: Convexity meningioma associated with empty sella presenting as primary amenorrhea. Neurochirurgia (Stuttg) 35(4):127-130, 1992 